\title{
Ecology of a ChaEtoceros socialis LAUder PATCH ON GEORGES BANK: DistRIBUTION, MicROBIAL Associations, AND GRAZING LOSSES
}

By Michael E. Sieracki, Dian J. Gifford, Scott M. Gallager and Cabell S. Davis
$T_{H}$ HE PRESENCE OF PATCHES and layers in marine pelagic ecosystems may play an important role in providing food for higher trophic levels at concentrations high enough to support the metabolism. growth, and reproduction of the consumers. There has been a persistent enigma of average bulk water prey concentrations frequently being below that necessary for consumer growth, yet the consumer populations are observed to grow and persist (Lasker, 1975: Mullin, 1988). Concentrated patches or layers of prey organisms are not accurately sampled by traditional means such as net tows, bottle sampling, and even standard CTD and in situ fluorescence profiling.

The formation of a subsurface chlorophyll maximum ( $\mathrm{SCM}$ ) during the late spring and early summer in temperate waters is well established (Steele and Yentsch. 1960). This maximum is most likely caused by the combination of sinking of larger phytoplankton cells from surface waters following nutrient depletion, and the establishment of a seasonal pycnocline within the euphotic zone ( $\mathrm{Ja}$ mart et al., 1977). This combination of biological and physical factors probably controls the composition of the SCM and its vertical extent. In some cases the SCM could be vertically compressed enough to form a thin layer, on the order of several meters thick. It is likely that if such layers are common in the marine environment, consumers have adapted to

Michael E. Sierachi, Bigelow Laboratory for Ocean Sciences, W. Boothbay Harbor, ME 04575 , USA. Dian J. Gifford, Graduate School of Occanography, University of Rhode Island, Narragansett, RI. USA 02882. Scoti M. Gallager and Cabell S. Davis. Woods Hole Oceanographic Institution. Woods Hole, MA. USA 02543. exploit this resource, and our observations. based on inadequately resolved sampling and average food concentrations over the water column. would lead to erroneous conclusions.

Chain-forming diatoms of the genera Thallasiosira and Chatoceros often dominate the microphytoplankton on Georges Bank and in the Gulf of Maine during late spring and early summer. These organisms have been observed regularly since the survey cruises of Bigelow in the early part of this century (Bigelow, 1924). The assemblage in the Gulf of Maine can consist of $>30$ species of Chaetoceros alone (Lillick, 1940). More recent studies demonstrate that Chaetoceros is a dominant genera in coastal waters of the Northwest Atlantic (Marshall and Ranasinghe. 1989). These studies, using traditional methods, were designed to map large-scale features such as the entire Gulf of Maine, Georges Bank, or the coastal U.S. waters. Smaller scale features such as patches and layers of cells are not resolved. Such features are undoubtedly important from the organisms" perspective as the conditions for growth and loss due to grazing or senescence must operate at the spatial scale of the cells. New technologies, such as the video plankton recorder (VPR), permit resolution of plankton distributions in situ that approach biologically relevant scales (Davis et al., 1992).

Chaetoceros sociales commonly occurs as chains wrapped into large. hollow spheroidal colonies (Rines and Hargraves, 1988). The colonies are large enough to be visible to the naked eye and can be easily confused with Phaeocystis colonies when viewed in bulk water samples without a microscope. The colonies have been observed to contain a variety of epiphytic algae attached to their surfaces (J. Rines, personal communication).

We encountered an extremely dense and vertically compact patch of $C$. socialis colonies while making a transect with the towed video plankton recorder on the southern flank of Georges Bank in early June 1994 and 1995. It was observed again in late May 1997 using standard hydrographic methods. The patch was associated with the pycnocline located at the top of the "cold pool" (Houghton et al., 1982) of water that flows in a southwest direction there along the southern flank of the Bank. The depth of the pycnocline, and associated patch, varied from 20 to $40 \mathrm{~m}$ in the region. The source and fate of the patch was not known. We report here our observations on the spatial structure of the patch, a previously undescribed microbial association within $C$. sociales colonies, and measurements of copepod grazing on the colonies.

\section{Methods}

The $C$. socialis patch was observed on the southern flank of Georges Bank in late May or early June of 1994, 1995. and 1997. To determine the distribution of the patch, two VPR tow-yo transects were made in 1995 (Fig. 1). The VPR methods used in this study are described in Davis et al. (1996). C. sociales was readily distinguishable in the VPR images by their shape, size, and texture (see Gallager et al., 1996. Fig. 6G for example images). Phaeocystis colonies were seen in VPR images from other areas of the bank at different times of year, and their images had smoother outlines, smoother texture, and scattered less light 


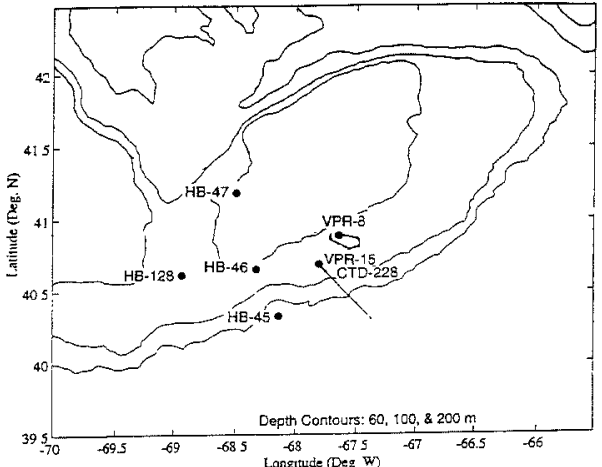

Fig. 1: The study site was on the southern flank of Georges Bank. Results are shown for two video plankton recorder transects (VPR-8 and VPR-15), and a CTD station (228) where water was collected for nutrients, chlorophyll, and plankton analyses as well as for the Calanus grazing experiment. Also show'n are four stations $(H B)$ sampled in 1920 by Henry Bigelow and referred to below.

than the $C$. sociales colonies. They tended to have prolate spheroid shapes. whereas the $C$. sociales colonies were more spheroidal in shape.

In 1997 colonies were collected from a station on the southern flank on 31 May in jars by scuba divers at 3-m-depth intervals through the layer of peak colony abundance. Colony counts were obtained directly from these jars by drawing multiple subsamples into the wide end of a glass $5 \mathrm{ml}$ pipet and counting the colonies in it using a dissecting microscope $(7.5 \times$ magnification) aboard ship. At least 100 colonies were counted from each depth.

In situ fluorescence, temperature. salinity, and transmissometry data were collected in addition to the video record of plankton distributions. The water column was sampled from depths of 5, 30, and $50 \mathrm{~m}$ using Teflon-lined Go-Flo bottles mounted on a CTD rosette. Samples were collected for analysis of major nutrients, chlorophyll, nanoplankton, and microzooplankton. Nutrients were analyzed with a Technicon Autoanalyzer-2 at the Marine Environmental Research Laboratory of the University of Rhode Island. Size fractionated chlorophyll (total, $<20$ and $<5 \mu \mathrm{m}$ ) was analyzed using a Turner Desighns model 10 fluorometer. Nanoplankton were analyzed by fluorescence imaging cytometry (Sieracki et al., 1993), and microzooplankton were preserved with $10 \%(\mathrm{v} / \mathrm{v})$ acid Lugol's solution, settled into counting chambers and

Table 1

Nutrients $(\mu \mathrm{M})$, particulate organic carbon, and extracted chlorophyll levels at CTD 228

\begin{tabular}{ccccccc}
\hline Depth. $\mathrm{m}$ & $\begin{array}{c}\mathrm{SiO}_{3}, \\
\mu \mathrm{M}\end{array}$ & $\begin{array}{c}\mathrm{PO}_{4}, \\
\mu \mathrm{M}\end{array}$ & $\begin{array}{c}\mathrm{NO}_{7}+\mathrm{NO}_{2}, \\
\mu \mathrm{M}\end{array}$ & $\begin{array}{c}\mathrm{NO}_{2}, \\
\mu \mathrm{M}\end{array}$ & $\begin{array}{c}\mathrm{POC}, \\
\mu \mathrm{g} \mathrm{L}\end{array}$ & $\begin{array}{c}\text { Chlorophyll, } \\
\mu \mathrm{g} \mathrm{L}\end{array}$ \\
\hline 5 & 0.89 & 0.20 & 1.77 & 0.08 & 179 & 3.31 \\
30 & 1.33 & 0.26 & 1.54 & 0.08 & 364 & 1.17 \\
50 & 1.05 & 0.10 & 0.99 & 0.06 & 493 & 0.84 \\
\hline
\end{tabular}

analyzed using a Zeiss Axiovert inverted microscope at a magnification of $200 \times$.

The colony matrix proved to be extremely delicate. Colonies were found only in water that was gently siphoned out of the top of Go-Flo bottles through wide diameter silicone tubing. Samples collected from the spigot at the bottom of the bottles did not contain intact colonies, nor was the colony matrix preserved in acid Lugol's samples. Water for the copepod grazing experiment (Gifford, 1993) was siphoned gently from the top of the 30-m Go-Flo bottle. Individual female Calanus finmarchicus were picked live from a $333-\mu$ m vertical net tow and added to replicate bottles containing the in situ assemblage including $C$. sociales colonies. Control bottles consisted of the assemblage without copepods. Bottles were wrapped in neutral density screen to recapitulate in situ light intensity and incubated on-deck on a plankton wheel whose temperature was maintained by flowing seawater. Bottles were harvested at times zero and $24 \mathrm{~h}$ and sampled for nanoplankton and microzooplankton prey as well as chlorophyll. The carbon content of individual copepods was measured using a Carlo Erba Model NA1500 elemental analyzer. Clearance rates were calculated using the equations of Frost (1972). Ingestion rates were calculated according to Marin et al. (1986).

\section{Results and Discussion}

\section{Water Column Properties and Community Structure}

The water column was stratified with respect to both salinity and temperature. The water temperature was $10.5^{\circ} \mathrm{C}$ at the surface and $6.6^{\circ} \mathrm{C}$ at $30 \mathrm{~m}$. The fluorescence maximum and transmission minimum associated with the $C$. sociales patch were located between $\sim 20$ and 40 $\mathrm{m}$. Nutrient measurements indicate that southern flank waters were relatively replete (Table 1). Silicate was somewhat depleted at the surface relative to deeper water, but phosphate and nitrate were higher in surface waters. Similarly. chlorophyll was higher in surface water than at 30 or $50 \mathrm{~m}$, suggesting that the 30 $\mathrm{m}$ Go-Flo bottle did not sample the maximum of the subsurface Chaetoceros patch. The area was hydrodynamically active due to tides and currents. and it was difficult to trigger the bottle closings within the $C$. sociales layer.

Phototrophic nanoplankton were larger and more abundant at the surface than at 30 or $50 \mathrm{~m}$ (Table 2 ). This resulted in a biomass (calculated from counting and sizing cells) at $5 \mathrm{~m}$ of $44 \mu \mathrm{gC} / \mathrm{l}$, double that of the biomass at 30 and $50 \mathrm{~m}$. Heterotrophic nanoplankton showed a maximum in abundance at $30 \mathrm{~m}$. Nanoplankton cells were smaller at this depth, so their biomass was relatively even through the water column (Table 2). Ciliate microzooplankton were more abundant by a factor of 4 in the $C$. socialis layer than in the upper water column (Table 3 ).

Chaetoceros sociales Distribution. The VPR\#15 was an on-bank to off-bank tow that transected the $C$. sociales patch. Peak colony abundances were closely associated with the top of the subsurface chlorophyll maximum near $25 \mathrm{~m}$ (Fig. $2 \mathrm{~A}$ ), and the colonies persisted throughout the SCM. Colonies were correlated with in situ fluorescence $\left(r^{2}=0.80\right.$, Fig. 2B). Colonies, although not quantified for the entire length of the tow. became more

Table 2

Population abundance, mean cell size, and hiomass of phototrophic and heterotrophic nanoplankton $(2-20 \mu \mathrm{m})$ at $\mathrm{CTD} 228$

\begin{tabular}{|c|c|c|c|c|}
\hline & $\begin{array}{c}\text { Depth. } \\
\text { m }\end{array}$ & $\begin{array}{c}\text { Cell } \\
\text { Abundance. } \\
\text { No.ml }\end{array}$ & $\begin{array}{c}\text { Mean Cell } \\
\text { Burolume, } \\
\mu \mathrm{m}^{3}\end{array}$ & $\begin{array}{c}\text { Biomus } \\
\mu \mathrm{gC} \mathbf{L}\end{array}$ \\
\hline \multirow[t]{3}{*}{ Phototrophs } & 5 & 3.074 & 65 & 44 \\
\hline & 30 & 1.856 & 53 & 22 \\
\hline & 50 & 1.816 & 50 & 211 \\
\hline \multirow[t]{3}{*}{ Heterotrophs } & 5 & 1.605 & 65 & 23 \\
\hline & 30 & 2.162 & 45 & 22 \\
\hline & 50 & 1.319 & 69 & 20 \\
\hline
\end{tabular}

*Calculated assuming a cell carbon densty of 220 fo $\mathrm{C}$ $\mu \mathrm{m}$ 
abundant farther along the tow where they caused a "white-out" of the video screen and saturated the fluorometer sensor (Fig. 3). Colony concentrations sufficient to cause the video screen to be filled are estimated to be $\sim 2,000-3,000$ per liter. so this is a minimum estimate of the peak colony concentration along this tow. $C$. sociales remained the dominant organism in the VPR images from the chlorophyll maximum depths for at least $20 \mathrm{~km}$ along this on-bank to off-bank track. In VPR\#8 (Fig. 4) the patch was intersected at a depth of $20 \mathrm{~m}$ at the southeast end of the "U"-shaped tow track. Both tows showed that the patch was narrowly compressed in the vertical. ranging in thickness from 5 to $15 \mathrm{~m}$. The extent of the patch along the bank (in the approximately east-west direction) was not determined.

In 1997 direct counts of the colonies in the fluorescence maximum layer showed densities ranging from 1,900 to 3,300 per liter (Fig. 5). The peak abundance corresponded to peaks in in situ fluorescence and beam attenuation. It was located above the $1 \%$ light level and at a density gradient formed primarily by colder water below $\sim 20 \mathrm{~m}$.

Microscope observations of individual colonies. Live individual colonies were examined under phase and fluorescence illumination using a compound microscope (with vibration isolation) aboard ship (Fig. 6). The chlorophyll in the $C$. sociales cells appeared brightly fluorescent (Fig. 6A) and dividing cells were common in the chains. There were very few attached epiphytes (Fig. 6B) as might be seen in senescent colonies. These observations gave the impression of relatively healthy, growing diatoms. Examination of about a dozen colonies at higher magnification ( $40 \times$ objective), revealed the presence of several heterotrophic protistan cells near the center of each colony, or the center of each lobe of multilobed colonies (Fig. 6, C and D).
Typically there were between 2 and 10 cells, each $\sim 6-8 \mu \mathrm{m}$ in diameter attached to the setae of the diatom near where they converge in the colony center. The protozoans were not morphologically distinctive at this magnification. Due to the jumble of setae at the colony center it was not apparent exactly how the protozoa were attached. They did not appear to be choanoflagellates, or have distinctive cell walls or appendages. Every colony examined contained these cells, and they were only seen near the colony center. Only occasionally were other cells observed attached or associated with the colonies. A few colonies were observed to have a single pennate diatom on their periphery, as has been observed on Phaeocystis colonies and on the setae of a variety of diatoms, including $C$. sociales (Taylor, 1982 and references therein). Flagellates were occasionally seen swimming through a colony. diamidinophenylindole (DAPI) staining of colonies revealed abundant, large $(\sim 1$ $\mu \mathrm{m}$ ) bacteria growing within the colonies on the setae. These were presumably growing on dissolved organic matter released by the diatom. These bacteria may be the food source for the heterotrophic protozoa found in the colony centers. In this case each colony may be a microbial consortia of interdependent organisms.

The observed regular pattern of a small number of similar cells located within every $C$. sociales colony suggests what may be a species-specific epi-symbiotic association. Such associations are common in tropical marine waters and in freshwater ponds and lakes (Taylor, 1982), where various ciliates, flagellates, and dinoflagellates have been observed attached to setae and cell walls of diatoms, including other species of Chaetoceros. To our knowledge this particular association has not been described in the literature. It is similar, however, to an observation reported by Elbrachter and Boje (1978) of the diatom Thalas-

Table 3

Abundance of microzooplankton (cells per liter) at CTD station 228

\begin{tabular}{ccccccc}
\hline & $\begin{array}{c}\text { Aloricate } \\
\text { Ciliates, } \\
\text { Depth. } \mathrm{m}\end{array}$ & $\begin{array}{c}\text { Aloricate } \\
\text { Ciliates, } \\
>20 \mu \mathrm{m}\end{array}$ & $\begin{array}{c}\text { Thecate } \\
>20 \mu \mathrm{m}\end{array}$ & $\begin{array}{c}\text { Dinoflagellates* } \\
\text { D-20sodinium }\end{array}$ & $\begin{array}{c}\text { Athecate } \\
\text { Dinoflagellates } \dagger\end{array}$ & Cerctium sp. \\
\hline 5 & 1,008 & 288 & 324 & 414 & 540 & 643 \\
30 & 5,058 & 756 & 72 & 594 & 216 & 126 \\
50 & 2,682 & 306 & 18 & 396 & 162 & 144 \\
\hline
\end{tabular}

*Heterotrophic cells, mostly Protoperidinitum sp. †Heterotrophic cells including Gymnodinium and Gyrodinium sp.
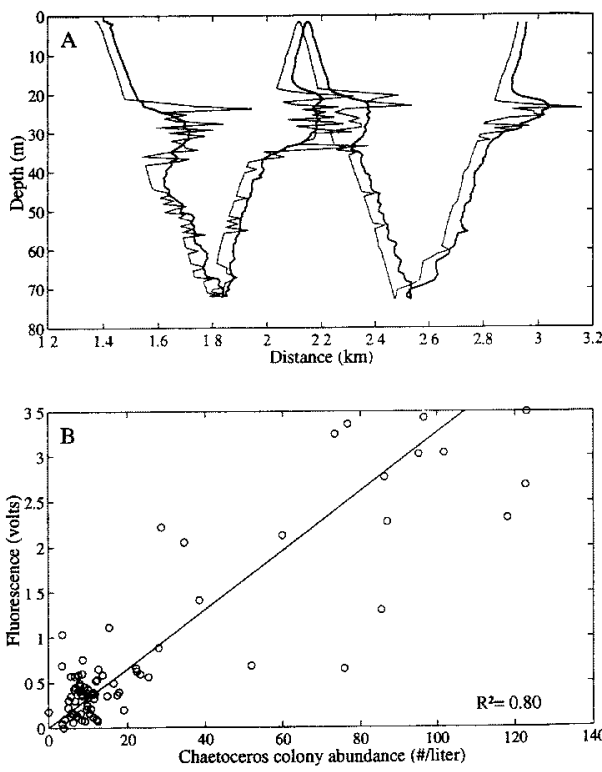

Fig. 2: (A) Vertical profiles of C. sociales colonies as determined from VPR images (thin line), and in situ fluorescence (thick line) from the first two tow'yos from the VPR\#15 transect. Values of colony abundance and fluorescence are added to the $x$-variable (position). The maximum value for Chaetoceros colony abundance in these two tow-yos is 228 per liter. The minimum value is zero (i.e., none seen in focus in a 2-s interval). The maximum fluorescence value is 4.27 and the minimum is 0.62 (volts). (B) Linear regression of in situ fluorescence versus colony abundance. The Chaetoceros data have been smoothed with a low-pass filter for comparison with the fluorometry data. The minima were subtracted from all values of both fluorescence and colony abundance to yield a $y=m x$ regression model.

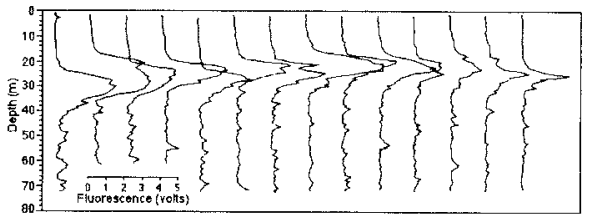

Fig. 3: Sequence of vertical profiles of in situ fluorescence taken from the beginning of VPR tow \#15. These alternating up and downcasts from the first hour of the tow have been offset by equal intervals to separate the profiles and show the sharpness of the subsurface chlorophyll maxima. The distance between successive profiles is $\sim 500 \mathrm{~m}$, and the total distance shown is $\sim 6.4 \mathrm{~km}$. Note the progressive sharpening of the peak along the transect and that the sensor was saturated at the peak of the eighth profile. 


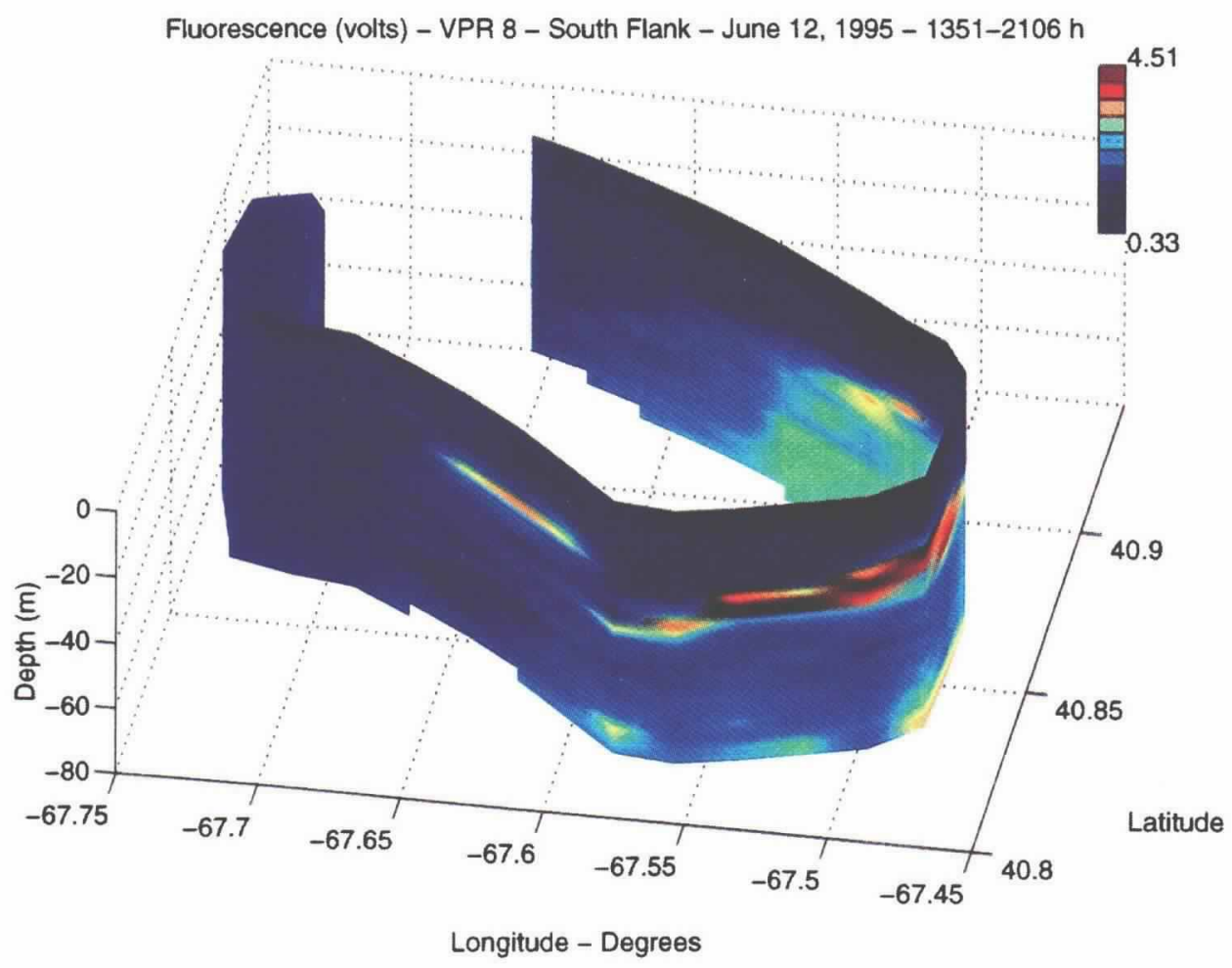

Fig. 4: Vertical section of in situ fluorescence along VPR tow \#8. This section intersected the $\mathrm{C}$. sociales patch at its southeastern end where high fluorescence was seen between 20 and $30 \mathrm{~m}$.

siosira partheneia, which forms hollow, cylindrical colonies with threads in the center. Small protozoa were observed in the center of these colonies that were found in high numbers in the Northwest African upwelling region. In contrast to the $C$. sociales, colonies these were colonized by a diverse assemblage of eukaryotic cells, including dinoflagellates, ciliates, amoeba, and pennate diatoms, as well as bacteria. Waterbury and Caron (1987) observed this $T$. partheneia consortium in Gulf Stream waters in the western North Atlantic.

Chlorophyll content and biomass of colonies. Individual $C$. socialis colonies contained a mean of $250 \mathrm{pg}$ chlorophyll per colony (range: $120-490, N=45$ ). Phaeopigment concentration was relatively high, averaging 800 pg per colony. Using a carbon to chlorophyll ratio of 50, this would yield an average carbon content of $12.5 \mathrm{ngC} \mathrm{colony}^{-1}$. Assuming a concentration of colonies of $2,000 \mathrm{~L}^{-1}$ at its peak, that would mean the $C$. sociales patch contained up to $25 \mu \mathrm{gC} \mathrm{L}^{-1}$, a biomass about equal to that of the phototrophic nanoplankton in the vicinity (Table 2).

Copepod grazing rates on $\mathrm{C}$. sociales colonies. Calanus finmarchicus females cleared $4.92 \pm 4.42(\mathrm{SD}) \mathrm{ml}$ copepod ${ }^{-1} \mathrm{~h}^{-1}$ of total chlorophyll and $6.21 \pm 2.84 \mathrm{ml}$ copepod $^{-1} \mathrm{~h}^{-1}$ on the $>20-\mu \mathrm{m}$ fraction, which was dominated by the $C$. socialis colonies. The ingestion rate of chlorophyll is equivalent to $44.7 \mu \mathrm{gC}$ copeod $^{-1}$ day $^{-1}$, or $52.7 \%$ of copepod body carbon. The copepods cleared nanoplankton and microzooplankton at rates of $6.62 \pm 7.92$ and $24.03 \pm 11.06 \mathrm{ml}$ copepod $\mathrm{h}^{-1}$, respectively, equivalent to ingestion of 2.51 and $1.39 \mu \mathrm{gC}$ copepod $^{-1}$ day $^{-1}$. Ingestion of heterotrophic prey accounted for 3.90 $\mu \mathrm{gC}$ copepod $^{-1}$ day $^{-1}$. Total per capita ingestion of autotrophic and heterotrophic prey was $48.6 \mu \mathrm{gC}$ copepod $^{-1}$ day $^{-1}$, equal to $57 \%$ of copepod body carbon $\mathrm{day}^{-1}$, sufficient to support basic metabolism, growth, and reproduction.

\section{Conclusions}

An extensive patch of colonial $C$. socialis was observed on the southern flank of Georges Bank in June of 1994, 1995, and 1997. Bigelow (1924) described a similar patch of $C$. socialis below $20 \mathrm{~m}$ in the same vicinity 75 years prior (17 May 1920) "congregated in such numbers that even the course-meshed net came back clogged" (stations HB46 and

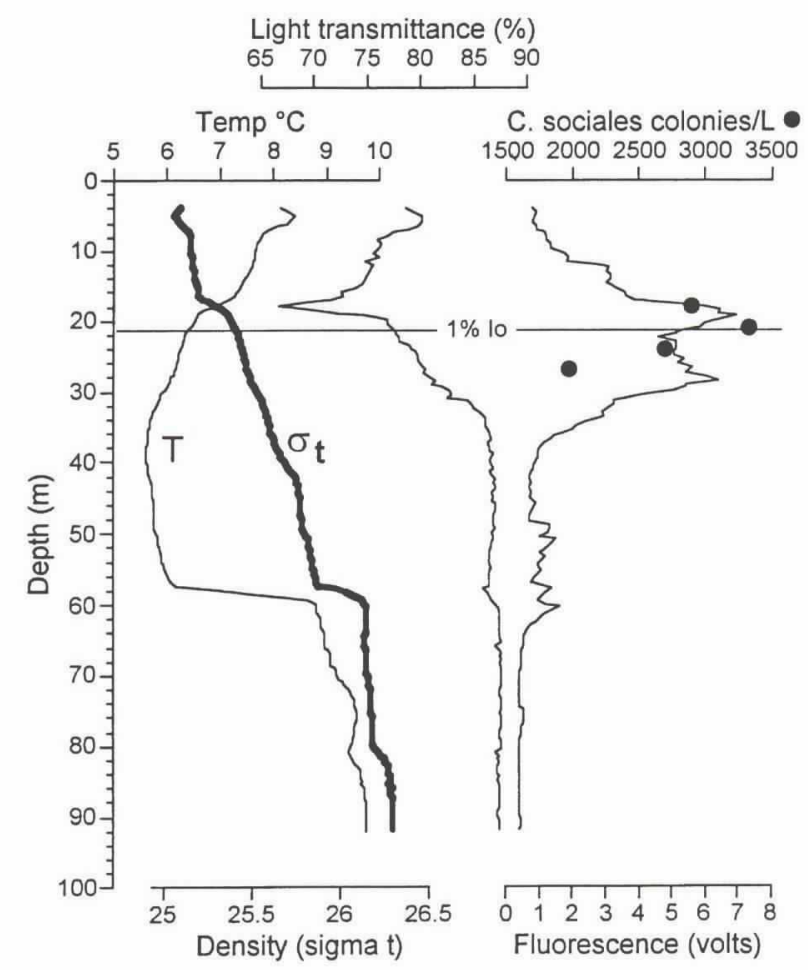

Fig. 5: Vertical profiles of temperature, density, beam attenuance, in situ fluorescence, and counts of Chaetoceros sociales colonies collected by scuba diving on 31 May 1997. The depth of the 1\% light level is shown (1\%Io). The coefficient of variation for the replicate colony counts ranged from 18 to $40 \%$. 

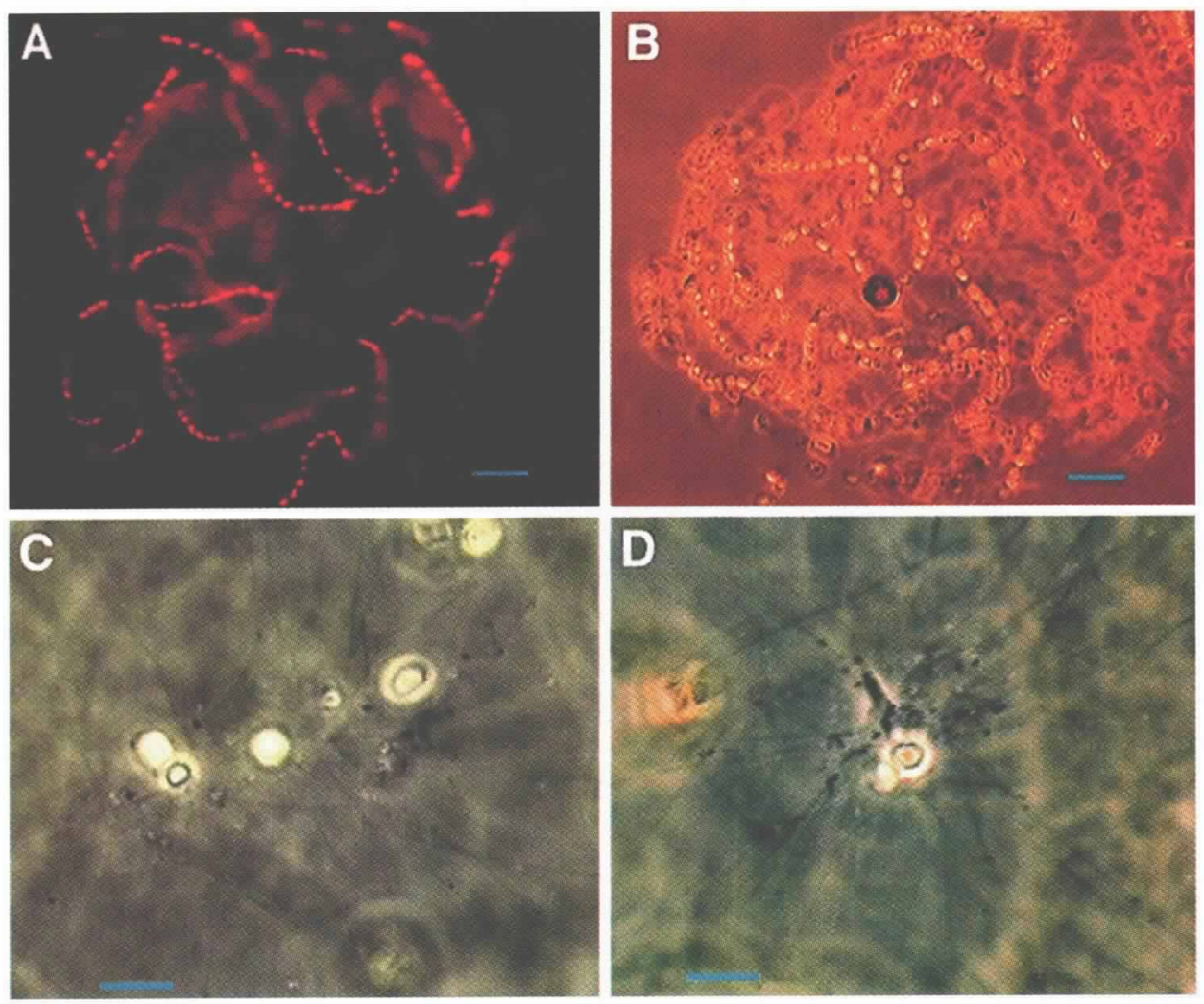

Fig. 6: Colony structure of C. sociales observed on the southern flank of Georges Bank. (A) Fluorescence micrograph of a colony showing its tertiary structure. (B) Transmitted phase illumination of a colony. Each colony had one or two of the larger distinctive diatom cells like that near the center of this image. ( $\boldsymbol{C}$ and $\boldsymbol{D})$ At the center of each colony, or lobe of multilobed colonies, the setae converge, and a small consortia of protozoa resides there. Between one and seven protozoan cells were observed at each center. Scale bars are $50 \mu \mathrm{m}$ in $\boldsymbol{A}$ and $\boldsymbol{B}$, and $10 \mu \mathrm{m}$ in $\boldsymbol{C}$ and $\boldsymbol{D}$.

HB 128, Fig. 1). In contrast, Sears (1941) conducted a survey of the phytoplankton composition on Georges Bank from March to June and did not report the presence of $C$. sociales, indicating that there are years when it does not occur in such abundance. More continuous yearly observations would be required to determine whether the presence or absence of the patch in late spring and early summer is the more common yearly phenomenon. If it were found to occur regularly every year, the $C$. sociales patch could act as an indicator of the physical, chemical, and biological conditions necessary for its concentration on Georges Bank over time scales that are relevant to climate change effects.

Colony density in the patch was on the order of several thousands per liter. There was a distinctive consortia of protozoa and bacteria at the center of each colony, at the convergence of the diatom setae. Female $C$. finmarchicus grazed on the colonies, as evidenced by the disap- pearance of chlorophyll in the $>20-\mu \mathrm{m}$ fraction, and on the nano- and microzooplankton located in the layer. The observed ingestion is well in excess of the daily respiratory requirement for $C$. finmarchicus females, suggesting that the C. sociales patch and its associated nano- and microplankton fauna provided a concentrated food resource in the water column. This result bears on the persistent enigma of average food levels in marine pelagic ecosystems where bulk water column concentrations of prey organisms are frequently inadequate to support the metabolic needs and growth of their consumers, yet the consumer populations grow and persist (e.g., Lasker, 1975; Mullin 1988). The presence of patches and layers as a source of concentrated prey for higher order consumers may well explain this paradox. The copepod's grazing activity may also impact the patch in terms of maintaining at least its upper boundary (assuming the lower boundary is set by the pycnocline).
At the average density observed with the VPR of 450 individual $C$. finmarchicus $\mathrm{m}^{-3}$, the copepods would clear $7 \%$ of the water in the patch on a daily basis. At the maximum density of $2,500 \mathrm{~m}^{-3}, 38 \%$ per day of the water would be cleared, suggesting that the impact of grazing by C. finmarchicus alone may significantly impact the structure and dynamics of the patch.

\section{Acknowledgements}

The research was supported by the National Science Foundation (award numbers OCE-9313678 to D.J.G., OCE9313679 to M.E.S., OCE-9313671, and OCE-9632596 and ONR grant N0001493-1-0602 to S.M.G. and C.S.D.). We thank E. Horgan, J.R. van Keuren, S. Plourde, P. Altalo, C. Ashjian, and A. Girard for assistance at sea, the captain and crew of the R.V. Endeavor, and F.J.R. Taylor for helpful discussions. US GLOBEC Contribution 94.

\section{References}

Bigelow, H.B., 1924: Plankton of the offshore waters of the Gulf of Maine. Bull. U.S. Bureau Fisheries, 40, 1-509.

Davis, C.S., S.M. Gallager and A.R. Solow, 1992 Microaggregations of oceanic plankton observed by towed video microscopy. Science, 257, 230-232.

S.M. Gallager, M. Marra and W.K. Stewart, 1996: Rapid visualization of plankton abundance and taxonomic composition using the video plankton recorder. Deep-Sea Res. II, 4 , 1947-1970.

Elbrachter, M. and R. Boje, 1978: On the ecological significance of Thalassiosira partheneia in the Northwest African upwelling area. In: Upwelling Ecosystems. R. Boje and M. Tonczak, eds. Springer-Verlag, Berlin, 24-31.

Frost, B.W., 1972: Effects of size and concentration of food on feeding behavior of the planktonic copepod Calanus pacificus. Limnol. Oceanogr., 17, 805-815.

Gallager, S.M., C.S. Davis, A.W. Epstein, A. Solow and R.C. Beardsley, 1996: High-resolution observations of plankton spatial distributions correlated with hydrography in the Great South Channel, Georges Bank. Deep-Sea Res. II, 4, 1627-1663.

Gifford, D.J., 1993: Consumption of protozoa by copepods feeding on natural assemblages. In: Handbook of Methods in Aquatic Microbial Ecology. P.J. Kemp, B.F. Sherr, E.B. Sherr and J.J. Cole, eds. Lewis Publishers, Boca Raton, FL, 723-729.

Houghton, R.W., R. Schlitz, R.C. Beardsley, B. Butman and J.L. Chamberlain, 1982: The middle Atlantic Bight cold pool: evolution of the temperature structure during 1979. J. Phys. Oceanogr., 12, 1019-1029.

Jamart, B.M., D.F. Winter, K. Banse, G.C. Anderson and R.K. Lam, 1977: A theoretical study of phytoplankton growth and nutrient distri- 
bution in the Pacific Ocean of the northwest U.S. coast. Deep-Sea Res., 24, 753-773.

Lasker, R., 1975: Field criteria for the survival of anchovy larvae: the relation between inshre chlorophyll maximum layers and successful first feeding. Fish. Bull., 73, 453-462.

Lillick, L.C.. 1940: Phytoplankton and planktonic protozoa of the offshore waters of the Gulf of Maine. Part II. Qualitative composition of the planktonic flora. Trans. Amer. Phil. Soc., 3I, 193-237.

Marin. V., M.E. Huntley and B.W. Frost. 1986: Measuring feeding rates of pelagic herbivores: analysis of experimental design and methods. Mar. Biol. 93, 49-58.

Marshall, H.G. and J.A. Ranasinghe, 1989: Phytoplankton distribution along the eastern coast of the U.S.A. VII. Mean cell concentrations and standing crop. Cont. Shelf Res., 9, 153-164.

Mullin, M.M., 1988: Production and distribution of nauplii and recruitment variability-putting the pieces together. In: Toward a Theory on Biological-Physical Interactions in the World Ocean. B. Rothschild, ed. Klewer Academic Publications, Boston, MA. 297-342.

Rines, J.E.B. and P.E. Hargraves. 1988: The Chaetoceros Ehrenberg (Bacillariophyceae) flora of Narragansett Bay, Rhode Island, U.S.A. Bibliotheca Phycologica 79, J. Cramer, Berlin.

Sears, M., 1941: Notes on the phytoplankton on Georges Bank in 1940. J. Mar. Res., 4.
$247-257$.

Sieracki, M.E., P.G. Verity and D.k. Stuecker. 1993: Plankton community response to sequential silicate and nitrate depletion during the 1989 North Atlantic spring bloom. Deep Sea Res. II, 40, 213-225.

Steele, J.H. and C.S. Yentsch, 1960: The vertical distribution of chlorophyll. J. Mar. Biol. Assoc. U.K., 39, 217-226.

Taylor, F.J.R., 1982: Symbioses in marine microplankton. Ann. Inst. Oceanogr., 5s, $61-90$.

Waterbury, J.B. and D.A. Caron, 1987: Microbiology. In: The Marine Environment of the U.S. Atlantic Continental Slope and Rise. J.D. Milliman and R.W. Wright, eds. Jones and Bartlett Publishers, Boston. 140-151. 